\title{
E-Government Applications: Factors Affecting the Employees' Satisfaction and Effectiveness in Greek Municipalities
}

\author{
Anna Maria Mouza \\ Professor \\ International Hellenic University \\ Department of Business Administration \\ TermaMagnesias, 62124 Serres, Greece \\ Eleni Kotridou \\ International Hellenic University \\ Department of Business Administration \\ TermaMagnesias, 62124 Serres, Greece
}

\begin{abstract}
After the economic crisis, in an attempt to enhance the administrative efficiency in Greece, various reforms were implemented regarding the e-government applications at public organisations. In this context, we explored the responses of 173 employees 'satisfaction and effectiveness of the systems' application considering variables such as Optimization, Citizens' services, Servants' efficiency, Assurance, Use of the internet, Quality of services and System's functional operation. An ordered logit model was applied for this particular case. The outcomes revealed that both the employees' satisfaction and the perceived effectiveness of the e-government use were significantly associated with the System 's functional operation and Servants' efficiency. The effectiveness was also significantly associated with Quality of services. Employees having lower educational level were more satisfied and denoted higher levels of effectiveness. These results will be valuable to policymakers for receiving decisions regarding the needed practices in order to advance the interaction between public and government services.
\end{abstract}

Key words: E-government, Public organizations, Municipalities, Satisfaction, Effectiveness, Greece.

\section{Introduction}

During recent years, new administrative and organisational reforms have been introduced in public organisations, due to the economic crisis in Greece. These are based on targeted e-government strategies, aiming to increase administrative efficiency by enriching the provided services to the citizens with added value and quality services, for facilitating the citizens' daily life. The formation of these relatively new information systems is provided centrally by the competent ministries for the benefit of the public bodies (Sourlas 2013). In the context of these reforms, the municipalities' services have been modernised to become more effective for the benefit of the administration and citizens. In the meantime, applied changes are focused on increasing the transparency of the procedures, adaptation of an exemplary and fairer administration system, acceleration of the citizens' affairs, and minimization of the public services costs (Alexopoulos et al. 2018, Delitheou et al. 2019).

Thus, the municipalities were invited to adjust to new management practices, adopting high-quality actions with the use of new Information \& Communication Technologies (ICT) (Goulas \& Kontogeorga 2013). These aimed to facilitate citizens' transactions, to contribute to the interoperability of their services with other public services, and to upgrade the administrative capacity (Alexopoulos et al. 2018). In particular, with the use of the new ICT, the citizens now have an active role in informing, in making decisions, and in participation at the launched public tenders procedures. Additionally, with the use of e-government applications, an effort was also made to improve the employees' efficiency and to strengthen citizens' confidence in local government administration. As a result, this enabled the municipalities' employees to become users of the interface, having access via personal codes, depending on their job obligations.

This paper presents the opinion of the employees among various municipalities, who work at the Regional Unity of Serres, Greece, regarding their satisfaction and the efficiency of the e-government applications for the benefit of the citizens. As there is limited research (Hahamis et al. 2005; Kitsios et al. 2019) regarding the employees' satisfaction and the efficiency of the e-governance use, this research aims also to cover this gap. 


\subsection{Literature Review}

Many suggestions have been proposed for the successful adaptation and diffusion of the e-government system. A few primary practices to take advantage of the e-government initiatives have been presented (Ndou 2004). Among others these practices include the systems' assessment regarding the implementation of future action plans, informing about the provided benefits, collaboration among government departments, training of the staff and the citizens to use the new facilities, clear government vision and strategy, as well as managing knowledge and change for continuous improvements. Additionally, four stages for the successful implementation of the service delivery (Clark 2003), were suggested including; publishing agencies information, users access to data and interaction with agencies, users' transactions with agencies and users' access to services of various agencies. Later, it was pointed out that it is at an initial stage regarding management, leadership, citizens' satisfaction, security, technology and technical expertise. Specifically, the e-government use of municipal websites applications was also examined to exploit opportunities and obstacles (Sarkar 2007). Moon (2002) focused on the practices and the effectiveness of the municipal e-governance and highlighted the main problems associated with the formation of the e-government, i.e. technical, financial and personnel shortage, and also its decreased contribution on reducing the administrative cost and the number of staff. The relation of the implementation of e-governance with three components has been also proposed (Schwester 2009). These factors are the human capital (full time IT staff), operating budgets and specialized hardware with the adequate e-government operation to cover their needs.

Prior to the economic crisis in Greece, the necessity of efficient applications to advance the interaction between public and government services was well recognized. As researchers targeted the weaknesses of the system to provide adequate information to satisfy the public, it was pointed out that the implemented initiatives and procedures presented reduced efficiency mainly due to the public administration complexity regarding its structure and operation (Markellos et al. 2007). Also, Hahamis et al. (2005) indicated the main obstacles which among other things included the funding, employees' skills and training, internet penetration (for the public sector, business and citizens) and the integration of the new services. The evaluation of the provided services at municipalities' websites revealed a lack of interactivity, feedback, e-services and applications when their quality depended on their geographical regions (Chatzopoulos \& Economides 2009). In the latter research, education for both citizens and staff was also proposed. Charalabidis et al. (2006) presented a multi-faced classification mechanism to develop, design and assess the offered services. Some researchers (Anthopoulos \& Tsoukalas 2006; Anthopoulos et al. 2007) suggested a new application to increase the citizens' satisfaction and the public administration effectiveness when others (Anthopoulos et al. 2010) identified the absence of national enterprise architecture in project design as the main reason for the failure of the e-government implementation.

After 2010, due to the economic crisis, many legislative and structural reforms took place in Greece (Goulas \& Kontogeorga 2013), to change the way municipalities work and increase their efficiency. At that time, the Greek government released a transparency plan to control corruption in different sectors (Sourlas 2013), where e-government was presented as a crucial element. For the proper evaluation of the local e-government projects, a model was recommended consisting of 14 factors, measuring the municipalities' performance and provision of online services (Lappas et al., 2015). Results of this research revealed a moderate performance and a low level of interaction, as it was mostly provided one-way information, indicating that no changes were made since 2006. Also, many researchers (Panayiotou \& Stavrou 2019, Kitsios et al. 2019) created original and conceptual frameworks regarding municipal electronic services which can be used to enhance the effectiveness, taking into consideration the system's information, service and quality and strategic preferences.

Recently, Alexopoulos et al. (2018) stated the citizens' ability to access in useful datasets, regardless of the limited financial resources provided by the government due to the economic crisis, although many enhancements must be fulfilled such as government spending, economic activity, more thematic categories, increased tools for data detection, multi-linguality sources, users' feedback and more extensive provision for metadata. The lack of personnel specialized in Information Technologies and the budgetary constraints are also indicated by other researchers (Maditinos \& Sidiropoulou 2020) as two main obstacles affecting the e-government adoption. Results of the E-Government Development Index (EGDI) for Greece show an improvement of the government operation and considerable efficiency of the public service delivery, as participation and involvement are ensured (Organisation des Nations Unies 2018). EGDI presented very high scores, being in the $35^{\text {th }}$ rank for 2018 as it was in 43rd for 2016, ensuring that many significant changes have been taken place regarding the way citizens react with public services. 


\section{Methodology}

\subsection{Participants}

Participants were employees working at the municipalities of Serres, Greece. In the self-reporting questionnaire were included the four demographic variables, i.e. Sex, Age, Educational Level and Work Status, as presented in Table 1. Additionally, seven variables were added, related to the use of e-government system in their service which are: Optimization, Citizens' services, Servants' efficiency, Quality of services, Assurance, Use of the internet and System's functional operation. Respondents were also asked, to indicate both their satisfaction and effectiveness of the egovernment adaptation in their service. Also, it was noted that the questionnaires were completed anonymously. Finally, 173servants responded to the request, and for all computational work SPSS 21.0 was used.

\subsection{Questionnaire}

Optimisation consisted of seven items and indicated the contribution of the e-government use to the organisation, citizens, servants and public administration as also reported by many researchers (Anthopoulos and Tsoukalas 2006; Delitheou \& Maraki 2010; Markellos et al., 2007). In this sense, items such as "The upgrading of the citizen-state relations" and "The simplification of procedures" were introduced.

Assurance was composed of four items related to the expected results. These items pointed out the use of e-government in the service regarding accountability, transparency, control mechanisms and compliance with management regulations as it has been highlighted by Oldfield (2017). Questions like" Reducing corruption rates" and "More rational decision-making" were also adopted. It is noted that for the above two, a -5point Likert-type scale was used, i.e. 1=not at all to $5=$ very much.

Citizens' services,present the employees' opinion regarding the benefits the citizens got from the provided services via the e-government use, related with the adequacy, availability and the received benefit of the provided data(Delitheou \& Maraki 2010), including six items like "Save time and money" and whether they "Are served promptly and quickly".

Servants' efficiency indicates the employees' perspective regarding their work efficiency when using the system. Thus questions like" Simplifies and facilitates my work" and" Increases the quality of the provided services" are included (see also Kitsios et al. 2019, regarding perceived usefulness criteria).

Quality of services. About the quality of the provided services, the employees expressed their aspect whether they are updated, important, reliable and sufficient as also proposed by Kitsioset al. (2019) regarding information quality criteria.

Use of the internet. It reflects the employees' intention to use the internet and manage any difficulties when using it. For this case, items like "I trust the use of the internet" and "I cope immediately with any problems incurred" were included.

System's functional operation, corporates three items concerning the employees' use of the e-government systems' operations and includes questions such as "It is friendly and functional to use" and "It is simple and easy to understand" (Kitsios et al. (2019) regarding the criteria of system quality).

For the above five variables, a 5-point Likert-type scale was adopted, $1=$ strongly disagree to $5=$ strongly agree.

\section{Results}

Table 1 shows demographic information about the participants. A Principal Component Analysis (PCA) was applied to locate the underlying dimensions of the data set, which consisted of 33 items. Results reveal seven components, as demonstrated in Table 2. The Kaiser-Meyer-Olkin measure verified the adequacy for the analysis, $\mathrm{KMO}=.908$. The Bartlett's Test of SphericityX ${ }^{2}(528)=5073.170, p<.000$, indicates that the correlations between the items were sufficiently large for PCA. Additionally, to determine the internal consistency of the scales, the Cronbach's alpha was computed for all seven dimensions, and all are considered to be acceptable (Table 3). In the same Table, the Means and the Std. Deviations are also presented. Table 4 shows the correlation coefficients between variables, where the variables Optimization and Assurance present high dependence. Quality of services and Servants' efficiency display the most considerable independence for significance at the .05 level.

To investigate the realized employees' effectiveness from the e-government use in the service, four demographic variables were considered, i.e. Sex, Age, Educational Level and Work Status. Additionally, seven variables regarding the use of e-government systems in their service were introduced which are: Optimization, Citizens' services, Servants' efficiency, Assurance, Use of the internet, Quality of services, and System's functional operation. 
Respondents were asked to reply as to whether they believe (1) or not (0) that thee-government use in their service is effectively applied, and it is considered as the dependent variable, which is a binary one. The estimation results are presented in Table 5, where one can see that employees' having lower educational levels indicate the effectiveness of the system. All coefficients of the explanatory variables are significant (Prob. 95\%, i.e. significance level $\alpha=.05$ ), while the coefficient of the System's functional operation is highly significant $(\alpha=.01)$. From Table 5 we also observe that the percent of change of the System's functional operation (135\%) indicates a high impact on the relative probability. It is noted that the null hypothesis of the high fitting of the model to the set of data is accepted, as Hosmer and Lemeshow statistic is: $X^{2}=12.168 \mathrm{df}=8, \mathrm{p}$-value $=.144$, ensuring the goodness of fit of the model, as already mentioned. Also, the values of the Cox \& Snell and the Nagelkerke $R^{2}$ statistics are .247 and.331, respectively, indicating that, comparatively, the explanatory power of the model can be considered satisfactory.

The results presented in Table 6refer to the model where the dependent variable is the binary variable Employees' satisfaction of the e-government use in the service, and the participants were asked whether they are satisfied (1) or not (0). From the presented results, we observe that all coefficients are highly significant $(\alpha=.01)$, and the percentages of change of the Servants' efficiency (176\%) indicates the strong impact on the relative probability. Regarding Hosmer and Leme show statistic it is: $X^{2}=3.248 \mathrm{df}=8$, p-value $=.918$, and the values for the Cox \& Snell and the Nagelkerke $\mathrm{R}^{2}$ statistics are .256 and .351 respectively, which are considered quite satisfactory.

\section{Discussion}

In this study we revealed that employees' satisfaction and the effectiveness of the e-government use are significantly associated with the System's functional operation and Servants' efficiency, indicating that they perceive its practical application and essential role on their job and productivity. This is also recognised by the latest results of the Egovernment Development Index (Organisation des Nations Unies 2018), as many positive changes have been established for its improvement and advancement. Additionally, the positive increase of the index is also presented by the denoted significance of this research, which associates the systems' effectiveness with the functionality and its use on the employees' everyday work concerning their duties and responsibilities. Also, the effectiveness of the egovernment use is associated with the Quality of services, indicating that the items of the variable are closely related to the systems' efficiency (Delitheou \& Maraki 2010).

Employees' having lower educational levels are more satisfied and indicated higher levels of effectiveness of the egovernment use. This can be explained by the fact that higher educated employees are expecting more outcomes and further positive consequences from the use of the system, as they understand the broadness of the procedures and they recognise the opportunities it can offer. Also, it is noted that the variables Optimization, Assurance, Citizens' services and Use of internet denoted no significant effects. However, concerning the employees' satisfaction regarding all listed variables, the upgrading of the services in the identified areas will make a significant contribution to their positive outlook, as the emerged and the expected benefits have been previously suggested by many researchers (Delitheou \& Maraki 2010; Markellos et al. 2007; Anthopoulos and Tsoukalas 2006).

\section{Conclusions}

During the last years, many reforms have been implemented regarding e-government applications. This research explored the employees' satisfaction and the effectiveness of the e-government applications, working in Greek municipalities. Results showed that both the employees' satisfaction and the perceived effectiveness of the egovernment use were significantly associated with the functional use and the efficiency of the system in their everyday work. The effectiveness was also associated with the quality of the provided services.

To our knowledge, there is no research regarding all the above variables relating the employees' satisfaction and the efficiency of the e-governance use in Greece. A limitation of this study is the small number of participants coming from a specific urban region of Greece. Further qualitative and quantitative research is needed to provide more information about the effectiveness of the system as well as all the necessary interventions and measures have to be applied. These results will be valuable to policy practitioners to ensure the possible provided outcomes of the system, to plan more precise actions to promote the role of e-governance on behalf of citizens and public organisations, and to strengthen and support its practical design and implementation for better results.

\section{References}

Alexopoulos, C., Loukis, E., Mouzakitis, S., Petychakis, M., \&Charalabidis, Y. (2018). Analysing the characteristics of open government data sources in Greece. Journal of the Knowledge Economy, 9(3), 721-753. 
Anthopoulos, L. G., Gerogiannis, V. C., \&Fitsilis, P. (2010). Measuring e-Government adoption by governments: the Greek case. In Comparative E-Government (pp. 353-370). Springer, New York, NY.

Anthopoulos, L. G., Siozos, P., \&Tsoukalas, I. A. (2007). Applying participatory design and collaboration in digital public services for discovering and re-designing e-Government services. Government Information Quarterly, 24(2), 353-376.

Anthopoulos, L. G., \&Tsoukalas, I. A. (2006). The implementation model of a Digital City. The case study of the Digital City of Trikala, Greece: e-Trikala. Journal of e-Government, 2(2), 91-109.

Charalabidis, Y., Askounis, D., Gionis, G., Lampathaki, F., \&Metaxiotis, K. (2006). Organising municipal egovernment systems: a multi-facet taxonomy of e-services for citizens and businesses. In International Conference on Electronic Government (pp. 195-206). Springer, Berlin, Heidelberg.

Chatzopoulos, K. C., \& Economides, A. A. (2009). A holistic evaluation of Greek municipalities' websites. Electronic Government, an International Journal, 6(2), 193-212.

Clark, E. (2003). Managing the transformation to e-government: An Australian perspective. Thunderbird International Business Review, 45(4), 377-397.

Delitheou, V., \&Maraki, M. (2010). Research into citizens' attitude towards electronic municipal services (e-local government). Journal of Public Administration and Policy Research, 2(3), 39-45.

Delitheou, V., Maraki, M., \&Trasanidis, C. (2019). The E-Government in Local Governance and Its Contribution to the Regional Development: A Comparative Study. International Relations, 7(09), 394-406.

Goulas, D., \&Kontogeorga, G. (2013). How did the economic crisis in Greece affected the steps in applying egovernment at the first degree self-government of Greece. Journal of Governance and Regulation, 2(4), 394406.

Hahamis, P., Iles, J., \& Healy, M. (2005). e-Government in Greece: Bridging the gap between need and reality. Electronic Journal of e-government, 3(4), 185-192.

Kitsios, F., Tsotoulidou, A. \& Kamariotou, M. (2019). User Satisfaction and Acceptance of the e-justice system in Greece, Proceedings of the 8th International Symposium \& 30th National Conference on Operational Research, Patra, Greece, pp. 131-135.

Lappas, G., Triantafillidou, A., Yannas, P., \&Kleftodimos, A. (2015, December). Local e-government and edemocracy: An evaluation of Greek municipalities. In International Conference on e-Democracy (pp. 134150). Springer, Cham.

Maditinos, D., \& Sidiropoulou, N. (2020). Incentives for the adoption of e-government by Greek municipalities. International Journal of Economics and Business Administration, VIII, (1), 298-326.

Markellos, K., Markellou, P., Panayiotaki, A., \&Stergianeli, E. (2007). Current state of Greek E-Government initiatives. Journal of Business Systems, Governance and Ethics, 2(3), 67-88.

Moon, M. J. (2002). The evolution of e-government among municipalities: rhetoric or reality?.Public administration review, 62(4), 424-433.

Ndou, V. (2004). E-Government for developing countries: opportunities and challenges. The electronic journal of information systems in developing countries, 18(1), 1-24.

Oldfield, J. (2017). Overview of National Approaches to Anti-Corruption Packages. Transparency International, Anticorruption Helpdesk. Transparency International. Retrieved from https://knowledgehub.transparency.org/helpdesk/overview-of-national-approaches-to-anti-corruptionpackages.

Organisation des Nations Unies. 2018. United Nations E-Government Survey 2018: Gearing E-Government to support transformation towards sustainable and resilient societies. New York, NY: United Nations.

Panayiotou, N., \&Stavrou, V. (2019). A proposed maturity assessment framework of the Greek local government Web Electronic Services. Transforming Government: People, Process and Policy. The current issue and full text archive of this journal is available on Emerald Insight at: www.emeraldinsight. com/ 1750-6166.htm

Sarkar, S. (2007). E-government adoption and diffusion. In 5th International Conference on E-governance ICEG-2007, Computer Society of India-Special Interest Group on E-governance, Hyderabad, India.

Schwester, R. (2009). Examining the barriers to e-government adoption. Electronic Journal of e-government, 7(1).

Sourlas G. (2013). "Transparency" National Anti-Corruption Action Plan. Hellenic Republic Ministry of Justice, Transparency \& Human Rights. General Secretariat for Transparency \& Human Rights. 1-119. 
Table 1: Demographic and work-related details of the sample considered

\begin{tabular}{lcc}
\multicolumn{1}{c}{ Total } & $\mathrm{N}$ & $\%$ \\
\hline \multicolumn{1}{c}{ Sex } & 173 & $100 \%$ \\
\hline Male & 70 & \\
Female & 103 & 40.5 \\
\hline \multicolumn{1}{c}{ Age } & & 59.5 \\
\hline Less than 25 years & 1 & \\
26-35 years & 8 & 0.6 \\
36-45 years & 76 & 4.6 \\
46-55 years & 74 & 43.9 \\
56 years and more & 14 & 42.8 \\
\hline \multicolumn{1}{c}{ Educational Level } & & 8.1 \\
\hline Senior High School & 52 & \\
Technical Institution & 34 & 30.1 \\
University & 64 & 19.7 \\
Post Graduate & 22 & 37.0 \\
Ph.D. holders & 1 & 12.7 \\
\hline \multicolumn{1}{c}{ Work Status } & & 0.6 \\
\hline Administrator & 146 & 84.4 \\
Head officers & 21 & 12.1 \\
Directors & 6 & 3.5 \\
\hline
\end{tabular}

Table 2: Principal Component Analysis

\begin{tabular}{|c|c|c|c|c|c|c|c|}
\hline \multirow{2}{*}{ Variables/Items } & \multicolumn{7}{|c|}{ Component } \\
\hline & 1 & 2 & 3 & 4 & 5 & 6 & 7 \\
\hline $\begin{array}{l}\text { Optimization } \\
\text { The use of e-government contributes to: }\end{array}$ & & & & & & & \\
\hline the use of premium practices & .771 & & & & & & \\
\hline theeffectivenessofPublicAdministration & .770 & & & & & & \\
\hline the simplification of procedures & .767 & & & & & & \\
\hline the communication between the state and the citizen & .760 & & & & & & \\
\hline the strengthening of the democraticprocesses & .733 & & & & & & \\
\hline the upgrading of the citizen-state relations & .724 & & & & & & \\
\hline reducing the amount of bureaucracy & .690 & & & & & & \\
\hline $\begin{array}{l}\text { Citizens' services } \\
\text { Regarding the use of the provided services I believe } \\
\text { that the citizens }\end{array}$ & & & & & & & \\
\hline benefit from their use & & .867 & & & & & \\
\hline save timeandmoney & & .803 & & & & & \\
\hline are served promptly and quickly & & .789 & & & & & \\
\hline are using the services at an increasing rate & & .723 & & & & & \\
\hline are satisfied with the adequacy of the information & & .712 & & & & & \\
\hline receive the available data quickly and safely & & .698 & & & & & \\
\hline $\begin{array}{l}\text { Servants' efficiency } \\
\text { The use of the system }\end{array}$ & & & & & & & \\
\hline simplifies and facilitates my work & & & .859 & & & & \\
\hline $\begin{array}{l}\text { increases the efficiency and effectiveness of my } \\
\text { work }\end{array}$ & & & .841 & & & & \\
\hline reduces the service time for citizens & & & .835 & & & & \\
\hline reduces my workload & & & .808 & & & & \\
\hline
\end{tabular}




\begin{tabular}{|c|c|c|c|c|c|}
\hline increases the quality of the provided services & .802 & & & & \\
\hline $\begin{array}{l}\text { Assurance } \\
\text { The use of e-government contributes to }\end{array}$ & & & & & \\
\hline reducing corruption rates & & .795 & & & \\
\hline $\begin{array}{l}\text { compliance with the rules governing Public } \\
\text { Administration }\end{array}$ & & .781 & & & \\
\hline law observance as a control mechanism & & .778 & & & \\
\hline more rational decision-making & & .759 & & & \\
\hline $\begin{array}{l}\text { Use of the internet } \\
\text { Regarding the use of the internet at my work }\end{array}$ & & & & & \\
\hline I use the internet without any problem & & & .795 & & \\
\hline I trust the use of the internet & & & .771 & & \\
\hline I cope immediately with any problems incurred & & & .769 & & \\
\hline I want to use it to manage my work & & & .737 & & \\
\hline $\begin{array}{l}\text { Quality of services } \\
\text { Regarding the quality of the provided services }\end{array}$ & & & & & \\
\hline are up to date & & & & .856 & \\
\hline are important & & & & .786 & \\
\hline are reliable & & & & .764 & \\
\hline are sufficient & & & & .718 & \\
\hline $\begin{array}{l}\text { System's functional operation } \\
\text { Regarding the use of the e-government systems } \\
\text { operations by me }\end{array}$ & & & & & \\
\hline It is friendly and functional to use & & & & & .791 \\
\hline It is simple and easy to understand & & & & & .780 \\
\hline It is well organised & & & & & .761 \\
\hline
\end{tabular}

Extraction Method: Principal Component Analysis.

Table 3: Cronbach's Alpha, Mean and Standard Deviation of the variables

\begin{tabular}{|l|c|c|c|c|}
\hline Variables & $\begin{array}{c}\text { Cronbach's } \\
\text { Alpha }\end{array}$ & Mean & $\begin{array}{c}\text { Std. } \\
\text { Deviations }\end{array}$ & $\begin{array}{c}\text { No. of } \\
\text { items }\end{array}$ \\
\hline Optimization & .925 & 3.682 & .803 & 7 \\
\hline Citizens' services & .920 & 3.781 & .871 & 6 \\
\hline Servants' efficiency & .946 & 3.676 & .950 & 5 \\
\hline Assurance & .931 & 3.565 & .844 & 4 \\
\hline Use of the internet & .868 & 4.070 & .806 & 4 \\
\hline Quality of services & .892 & 3.797 & .781 & 4 \\
\hline $\begin{array}{l}\text { System's functional } \\
\text { operation }\end{array}$ & .869 & 3.703 & .832 & 3 \\
\hline
\end{tabular}

Table 4: Correlation Matrix of Dimensions

\begin{tabular}{|l|c|c|c|c|c|c|c|}
\hline Variables & Optimisation & $\begin{array}{c}\text { Citizens' } \\
\text { services }\end{array}$ & $\begin{array}{c}\text { Servants' } \\
\text { efficiency }\end{array}$ & Assurance & $\begin{array}{c}\text { Use of } \\
\text { internet }\end{array}$ & $\begin{array}{c}\text { Quality } \\
\text { of } \\
\text { services }\end{array}$ & $\begin{array}{c}\text { System's } \\
\text { functional } \\
\text { operation }\end{array}$ \\
\hline Optimization & 1.00 & & & & & & \\
\hline Citizens' services & $.436^{* *}$ & 1.00 & & & & & \\
\hline Servants' efficiency & $.521^{* *}$ & $.500^{* *}$ & 1.00 & & & & \\
\hline Assurance & $.650^{* *}$ & $.383^{* *}$ & $.410^{* *}$ & 1.00 & & & \\
\hline Use of the internet & $.405^{* *}$ & $.314^{* *}$ & $.421^{* *}$ & $.545^{* *}$ & 1.00 & & \\
\hline Quality of services & $.346^{* *}$ & $.562^{* *}$ & $.164^{*}$ & $.429^{* *}$ & $.328^{* *}$ & 1.00 & \\
\hline $\begin{array}{l}\text { System's functional } \\
\text { operation }\end{array}$ & $.372^{* *}$ & $.531^{* *}$ & $.403^{* *}$ & $.333^{* *}$ & $.435^{* *}$ & $.477^{* *}$ & 1.00 \\
\hline
\end{tabular}


**. Correlation is significant at the 0.01 level (2-tailed).

*. Correlation is significant at the 0.05 level (2-tailed).

Table 5: Dependent variable: Effectiveness of the e-government use in service

\begin{tabular}{lccccccc}
\hline & Est. coeff. $\left(\hat{b}_{j}\right)$ & $\mathrm{SE}\left(\hat{b}_{j}\right)$ & $\begin{array}{c}\text { Wald } \\
\text { statistic }\end{array}$ & $\mathrm{p}$-value & $\begin{array}{c}\text { OR } \\
\left(e^{\hat{b}_{j}}\right)\end{array}$ & $\begin{array}{c}\text { Percent } \\
\text { of } \\
\text { change }\end{array}$ & 95\%CI \\
\hline Educational Level & -.409 & .174 & 5.508 & .019 & .665 & $-33.5 \%$ & $.472-.935$ \\
\hline $\begin{array}{l}\text { System's functional } \\
\text { operation }\end{array}$ & .858 & .283 & 9.193 & .002 & 2.359 & $135 \%$ & $1.354-4.108$ \\
\hline Servants' efficiency & .477 & .209 & 5.192 & .023 & 1.611 & $61.1 \%$ & $1.069-2.428$ \\
\hline Quality of services & .716 & .28 & 6.486 & .011 & 2.046 & $104 \%$ & $1.179-3.550$ \\
\hline Const. & -5.994 & 1.391 & 18.585 & .000 & .002 & & \\
\hline
\end{tabular}

Table 6: Dependent variable: Employees' satisfaction of the e-government use

\begin{tabular}{lccccccc}
\hline & Est. coeff. $\left(\hat{b}_{j}\right)$ & $\mathrm{SE}\left(\hat{b}_{j}\right)$ & $\begin{array}{c}\text { Wald } \\
\text { statisti } \\
\mathrm{c}\end{array}$ & $\mathrm{p}$-value & $\left.\begin{array}{c}\text { OR } \\
\left(\hat{b}_{j}\right.\end{array}\right)$ & $\begin{array}{c}\text { Percent } \\
\text { of } \\
\text { change }\end{array}$ & 95\%CI \\
\hline Educational Level & -.588 & .190 & 9.586 & .002 & .556 & $-44.4 \%$ & $.383-.806$ \\
\hline $\begin{array}{l}\text { System's functional } \\
\text { operation }\end{array}$ & .848 & .262 & 10.517 & .001 & 2.336 & $133 \%$ & $1.399-3.900$ \\
\hline Servants' efficiency & 1.015 & .282 & 12.976 & .000 & 2.760 & $176 \%$ & $1.589-4.796$ \\
\hline Const. & -4.268 & 1.206 & 12.517 & .000 & .014 & & \\
\hline
\end{tabular}

